\title{
Framing of Women with Disabilities on Online Media
}

\author{
Bintan Humeira, M.Si \\ Dept. of Islamic Comm. and Broadcasting \\ Syarif Hidayatullah State Islamic University (UIN) \\ Jakarta, Indonesia \\ E-mail: bhumeira@ymail.com
}

\author{
Siti Nurbaya, M.Si \\ Dept. of Islamic Comm. and Broadcasting Syarif Hi- \\ dayatullah State Islamic University/ (UIN) \\ Jakarta, Indonesia \\ E-mail: noerbaya79@gmail.com
}

\begin{abstract}
Media has become the dominant source of information not only for individual but also for the community in obtaining a picture of reality. In the construction process of reality, language is the main element. Language is the central instrument for telling reality. The choice of words and how the presentation of a reality contributes to the structure of the construction of reality and the meaning that arises from it. Therefore, in this construction process there is a tendency of media that may be biased in constructing an event or people, one of which is about women and disable groups. Media represent women with disabilities to be a weak figure when compared with disabled men. Men with disability are seen more powerful when he is able to work while women are more seen as a figure that needs to be pitied and highly dependent on others. This study aims to find out how the online media frame issue about women disabilities, whether it shows more empowerment or remain trapped in gender bias. For this reason, this research uses constructivism paradigm which see the media not as a free and neutral channel but as a subject that constructs reality. The construction theory of the social reality sees that social reality is often manifest as a symbolic reality framed by the media with certain news strategy through the selection of words, images, and the use of view to affirm the interests of the media seeing an issue. Therefore, this research uses Pan and Kosicki framing analysis technique to find how media frame the issue of women with disabilities. The result shows that online media frame the issue of the women with disabilities in gender bias.
\end{abstract}

Keywords: women; disability; online media; framing

\section{INTRODUCTION}

Discrimination against disabled people is still an important discussion among social activists in Indonesia, especially on the issue of disabled women. The discrimination happens not only because of their disability, but also because of their identity as women. One example of discrimination forms of disabled women we often see in the media in framing the news. Media as the fastest source of information and accessible by the community can serve to lead the case, influence the community, and contend or provide public understanding of an event. Therefore, writing the news with a balanced perspective without seeing the shortcomings of a person becomes very important and as a standardization of the professional ethics of a journalist.

Disabled people are often regarded as unproductive citizens and unable to perform their duties and responsibilities, affecting their rights to be ignored. They are often marginalized in the mass media discourse in Indonesia. The marginalization effort through the mass media discourse towards disabled groups appears in the news that uses offensive language structure.

In the study of the relationship between mass media and disabled people in the UK, Quinlan and Bates [1] demonstrated that portraying people with disabilities as supercrips gives positive feedback to people with disabilities and affects their self-identity positively. They are more likely to build positive and confident self-identity when media stories exposed about the accomplishments of individuals with disabilities. In contrast, this might be since media representations of people with disabilities are predominantly stigmatizing. Quinlan and Bates [1] argued that mass media have a great influence on society's perceptions of people with disabilities. Wood [2] said that the disabled people have less participation in social life. The physical condition of a person blocks their activities and it makes them tend to be eliminated in society. Further, Wood [2] argues that in England context, since 1970 there has been a paradigm shift believing that disabilities are a result of social construction that limits their activities. However, the media tends not to adapt to their perspective that prioritize the equality. Therefore, Wood [2] argues that the lack of disabled people representation in the media, especially in the production process, affects the content displayed in the media discourse about the disabled people continue to frame discrimination against disabilities in social life.

In the context of the social life of Indonesian society, a person with a physical disability is sometimes considered as an imperfection, or something abnormal. Thus, they belong to a group to be pitied and even deserve help in form of charity and alms from the perfect ones. In some cases, of course, we can see that disabled people often earn money with the compassion of their imperfection. In the mass media, the disabled people are considered object of pity and joke [3]. Various social constructions make the disabled people have a social perception of the identity of disability as a group of helpless individuals who need help.

In this study, the research conducted a preliminary observation of the newspaper articles from online media that shows that the media is still trapped in the disability discrimination mainstream that is framed in the language structure used. The media shows that there is a framed tendency in gender bias, favoring men rather than women. In the case of rape trials, disabled women as victims are framed by highlighting their disadvantages as disabled women, not as victims with psychological and physical impact due to the sexual violence they experienced. Conversely, perpetrators are framed as good men. The media look more to their disability as a condition that prevents the victims to follow the trial as 
normal people. This tends to give bad perception to disabled people, especially women. They become public consumption in shaping gender-biased news in society.

The depiction is very contrary to the ideal conditions that should be realized by the media institutions in Indonesia. Media is obliged to protect the disabled people who are a minority group in Indonesia. The protection of minority groups in the media in Indonesia is guaranteed in the Broadcasting Behavior Guidelines - Broadcast Program Standard (P3-SPS) issued by the Indonesian Broadcasting Commission (KPI) in Article 15 paragraphs 1 and 2 (P3-SPS KPI, 2009) containing the obligation to pay attention to and to protect the rights and interests of minority and marginalized groups, including disabled people.

In the regulation, it is written that broadcast media programs are prohibited to: a) contain content that may generate or reinforce negative stereotypes about the groups; b) make these groups a mockery or ridicule; and / or c) exploit these groups to gain the maximum benefit for broadcasters without thinking of adverse impacts to viewers (P3-SPS KPI, 2009). Not only the regulation of broadcast media, print media ethics in Indonesia such as journalism ethics code of Alliance of Independent Journalists (PWI) also states the same ban.

The development of media that is rapid and difficult to limit encourages the birth of media that has an extraordinary impact on the communication pattern and information access that is more intensive, open, and participatory. The existence of various means of multimedia allows individuals and groups within society to produce and express their own messages, establish their cultural identity, as well as share and exchange their respective experiences [4].

Online media has specific characteristics that are not owned by mainstream media. Some of the specific characteristics of online media over the internet include: 1) participatory, because internet technology allows every individual - who previously only become consumers of mainstream media - to produce their own content ; interactive, because online media enable two-way communication between message senders and audiences [5] ; accessible and affordable, because it is accessible to anyone and tends to be cheaper [6] and have connections that allow users to access information quickly and in accordance with their needs.

The ability of online media to bridge the interactions between individuals without being impeded by space and time constraints provides an opportunity for media workers to frame their news based on their interest. Peter L. Berger and Thomas Luckman in their book The Social Construction of Reality: A Treatise in the Sociology of Knowledge describe the social process through its actions and interactions, in which individuals continuously create a shared and experienced reality subjectively.

In studying the media, frame analysis shows how aspects of the structure and language of news affect other aspects. Frame analysis is the basis of cognitive structure that guides the perception and representation of a reality. According to Panuju, frame analysis is an analysis to unravel the ideology behind the writing of information. Through framing analysis, it can be seen how certain media highlight an issue that other media does not highlight, or how certain media minimize or even cover and eliminate a frame while other media highlight the frame.
Framing analysis sees the news discourse as a symbolic war arena between the parties concerned with the subject matter of discourse. Each party tries to convey their perspective to the audience. In this case each party seeks to accentuate the basis of their interpretation, claims or arguments by using symbolic and rhetorical languages that lead to certain connotations.

This view is expressed in the theory of the construction of social reality by Peter L. Berger and Thomas Luckmann, who says that in the process of constructing reality, language is the main element. Through language, events are conveyed and given a certain meaning in the minds of audiences. Thus, the language does not merely reflect reality, but also determines a image of an event or a person in the minds of audiences. Through language strategy, a similar event can have different meanings in the minds of audiences.

Framing the news is a strategy used in the process of reality construction by the media. Framing involves two aspects, issue selection and issue salience. Framing is selecting certain aspects of reality and giving emphasis in the text, such as defining the problem, what causes the problem, the moral evaluation and the solutions offered on the issue [7]. Fiske and Taylor argue that the emphasis of the issue salience is the process of making the piece of information more noticeable, meaningful or memorable to the audience, and it will increase the likelihood that the issue is accepted, processed and stored in memory [8].

\section{METHODS}

This research refers to a constructivism paradigm that sees news not as a real, neutral or value-free fact. News is a product of interaction between journalists and facts. In the process of writing news, journalists use their perspective to make sense of reality. This research would like to describe how the issue of trial of rape against women with disabilities is framed by the media. The object of this research is a news about the trial of rape against disable woman which is published by kompas.com in 2016.

This research uses Pan and Kosicki framing model that includes syntactical structure, script structure, thematic structure, and rhetorical structure. These four framing structures show how the media compose the news, use the way of writing, and cite statements and detailed explanations to direct the readers to the formation of a particular perception. This research does not see the media as a free and neutral channel but as a subject that constructs reality. Workers involved in producing messages also include their view, bias, and partiality. In the view of social construction, news is not an event or fact in a true sense; it is rather a product of interaction between journalists and facts. In the process of internalization, journalists throw themselves to make sense of reality.

\section{RESULT AND DISCUSSION}

The research shows that media is still trapped in the disability discrimination mainstream that is framed in the language structure used. The media shows that there is a framed tendency in gender bias, favoring men rather than women. Media portrayed disabled women in the news by emphasizing their weakness and considered not to have the 
ability to speak for themselves. The news report tends to be biased in understanding the incident of rape against disable women.

Research analysis of the four framing structures in the text shows that the syntactic structure of news is indicated by quoting many statements of the victim's family and co-workers of the suspect to form a biased opinion of the victim and the suspect of rape. The number of quoted source statements analysis of the four framing structures in the text shows suggest that the victim is a person who has weaknesses from the aspects of physical and mental health, whereas on the contrary the suspect is displayed as a good person figure.

The news report in kompas.com uses the victim's physical and mental health disorder to shape the readers' opinion. The report uses four quotes of the victim's family that explain more about the condition of the victim who had experienced seizures in the past when the victim was in a state of distress. But it does not tell when that condition occurs and why it is important. Through quotations of sources, the news reports construct the news frame that the trial of rape would make the victim depressed and experienced convulsions. The frame is reinforced by citing the victim's family statement that they are carrying a stock of medicine for the victim to face the trial. The phrase "stok obat (drug stock)" gives the impression that the victim is a seizure disorder sufferer until the family needs to provide stock of medicine to overcome it. However, there is no medical explanation what kind of illness the victim suffered by citing expert sources. In medical diagnosis, seizures may be a common symptom of some diseases. Though the news report was told that the victim has a history of seizures that it means referring the victim as people with epilepsy. In medicine, epilepsy is a neurological disorder of the human brain, not a psychiatric or mental disorder. It means that people with epilepsy are not categorized as people who have mental disorders. They can still move and work like normal people. Thus, the tittle of news_"Sidang perkosaan perempuan disabel, Korban lupa diberi obat (Rape Trial of Disable Women, The victim forgot to take medicine" gives the impression that there is a certain impact of the condition of "forgetting to take medication" which may affect the victim in following the trial process. Furthermore, the subsequent statement in the report stating that the trial is the first experience of the victim so that the family is worried about what will happen in there. The statement leads the readers that the condition of the victim is not the same as a normal person. The phrase "khawatir kondisi di dalam seperti apa (worrying about the inside conditions)" seems to describe that the victim's condition will make the process of trial uncontrollable. In addition, the report uses the phrase "we pray unceasingly" that seems to lead the readers to imagine a bad situation that may occur due to the condition of the victim, hence need God help to overcome it.

The news report shows that the victim is a patient with health problems and disability more based on some quotes of her family, not citing from medical expert's explanation. The explanation of health problems ought to be based on analysis and medical reports. Media tried to rationalize the condition of the victim from the view of the victim's family which is positioned as a person who knows well the victim more than the other. The irony is media does not talk about the incident of the rape. The issue is more dominantly portrayed the victim as a person with a history of recurrent seizures who often endanger herself and others. The important things such as the impact of the incident rape on the physical and mental condition of the victim is not described at all in the news report. The impact of rape on the victim should be an important aspect in seeing how the crime of rape cannot be justified for any reason, and becomes an important aspect in understanding how the process of the court should be held fairly for both parties. Moreover, there is no text in the news report that refers to the victim's statements about her feelings and condition as a rape victim. The story of the victim is more narrated by others, who cannot really understand what is experienced by the victim. Thus, it seems media thinks the impact of rape on the victim is not an important aspect to be known by the reader.

The news bias on the rape trial case is also shown by framing strategies that defends the suspect rather than the victim. The defense is indicated by the statements of coworker of the suspect. Frame of the defense begins with the use of subheads "Pelaku mendapat dukungan (Suspected actors have support)". Media uses three quotes to create a more positive image of the suspect. Furthermore, the report uses the word "dozens of supporters" in order to show the large number of employees of the RSUD that support the suspects in the trial. Media seems to lead the readers' mind that there are many RSUD employees, co-workers of the suspect attend the court to support him. The media did not provide a detailed explanation of how many supporters were present. It attempts to construct more sympathetic view on the suspect. Moreover, the report tried to explain the facts by citing the statement of the supporters who said they came with voluntary, self-directed initiatives. The statement obviously aimed to emphasize the image of the suspect as a good person. The report highlighted fact of the presence of volunteered supporters to show how good relations of the suspect have with his friends. The report also quotes of the supporter's statements that they know the suspect as being polite, hardworking and friendly person.

The element of the script shows that media structured this rape trial report using $5 \mathrm{~W}+1 \mathrm{H}$. The report is presented by explaining what it is about, who the suspect and the victim, who was involved in the trial, when and where the trial was conducted, why the trial was held, and how the trial took place. The completeness of the script structure is shown by giving a bit of background of the rape incident, though there is no the chronology of it. Apparently, the news report is explained the trial only without intending to make the readers know how the rape incident occurred. Thus, it can be interpreted that the incident chronology of rape as the background of the trial is not an important aspect to be understood by readers. In other words, the structure of the script is only giving emphasis only on facts that support frames, and hiding parts are not supported. The chronological incident of rape and its impact on the victim's physical and mental condition are not parts that is necessary to be highlighted. Instead the media accentuated on the weakness of the victim as a disable woman. On the contrary, the media defends the suspect by highlighting the good side of the suspect according to his colleague's opinion.

The thematic structure of the text shows how the uses of propositions, sentences or inter-sentence relations 
construct a biased understanding. The text show that the thematic structure uses the element of details and coherence. The detailed element occurs in the description of the victim's health condition according to her family opinion. However, the family's explanation about the victim more accentuated the victim as a figure who has mental health problems that are considered unable to follow the trial process. Even the condition of the victim is considered to interfere with the process of trial. The use of detailed elements in explaining the victim's health problem seems to be aimed for building a poor image of the victim. The detailed elements show how the discourse developed by the media.

Therefore, the media also uses coherence elements for constructing the media frame through interwoven words or sentences in explaining facts. The coherence aspect is indicated by relating the trial process to the condition of the victim who forgot to be given the medicine the media uses the facts to construct the issue as if it is interconnected or has cause and effect. The coherence aspect in the news text is not just a technical matter of grammatical truth, but about the meaning that is shaped by the order of sentences. In this research, it is found that media directs the readers' mind to the conclusion that women with disability do not have the capability to follow the trial like a normal person. The fact that the victim forgot taken the medicine before the trial seemed to be important in the news. The frame of news is not about the trial process held fairly, but rather highlight the victim's weaknesses as disable women to follow the trial process. Moreover, there is an impression emerging from the text that the victim's testimony becomes questionable because of her poor condition. In contrast, the suspect is framed by media as a good person figure by his coworkers

In a framing strategy, the syntactic element of quoting a news source becomes an important part of building the principle of balance and impartiality in writing. The quotation of the source emphasizes that the report is written by journalists is not the opinion of the journalist alone, but the opinion of a person who has certain authority. The source citation becomes a framing device for three things. First, claim the validity or truth of the statement made by basing themselves on the claims of academic authority. Second, connect certain points of view to authorized officials. Third, discourage certain opinions or views associated with quotations or views of the majority so that the view appears to be distorted [9]. This research shows that kompas.com uses sources which have closeness with the victim and the suspect to claim that their source knows well the condition of them. The closeness is deemed to have a validity or truth claim that is acceptable to the views of most of readers. However, instead of citing the source to build objectivity, this strategy appears to provide a greater portion on a party and undermine or weaken the other. The research show that the rape suspects get a more positive framing than the victims as a woman with disability.

\section{CONCLUSION}

The study concluded that the frames used by the media tend to discriminate against dis- abled women. Women who are defective in the news are more framed than their physical weak- ness, not from the harm suffered as a rape victim. Instead, the actors are framed more positively. The framing strategy of the media shows that source selection (quotation) and the way of writing (script) get bigger portion. The sources are selected from people who can provide support the media frames, and are given a dominant portion of the quoted statements. In addition, the way media frames issues show that media compose reality and convey news to readers according to their frames. While the media seems to be trying to write news from the side of the suspect and the victim of rape, the sequence of the quotation and the selection of source quotation build the meaning that directs the reader to agree on the media frame. The media still miss important and diverse stories related to disabled people because of their persistence in the stereotypical portrayals.

\section{REFERENCES}

[1] M. M. Quinlan and B. R. Bates, "Gender, disability and cyborgs,” J. Res. Spec. Educ. Needs, 2009.

[2] L. Wood, A Critical Analysis of Media Representation of Disabled People. The Disability Planet, 2006.

[3] A. Muhammadun, "Disable and Construction of Social Injustice," Republika Daily, p. 10, 07-Dec-2011.

[4] J. Straubhaar, R. \& D. Larose, and Lucinda, Media Now: Understanding Media, Culture and Technology, 7th ed. Wadsworth: Cengange Leraning, 2009.

[5] T. Flew, New Media, 4th ed. Oxford, 2014.

[6] M. Poster, The Second Media Age. Cambridge: Polity Press, 1995.

[7] R. M. Entman, "Framing: Towards Clarification of a Fractured Paradigm. Journal of Communication," vol. 43, 1993.

[8] I. Hamad, Konstruksi Realitas Politik dalam Media Massa. Jakarta: Granit, 2004.

[9] Eriyanto, Analisis Framing, Konstruksi Ideologi, dan Politik Media. Yogyakarta: LKIS, 2002.

[10] Gamson, William. Croteau, David, et.al. Media Images and The Social Construction of Reality. Annual Review of Sosiology. 1992.

[11] Gergen, M. and Gergen, K.J. Social Constructionism: A Reader. London: SAGE Pub. 2003.

[12] Hamad, Ibnu. Konstruksi Realitas Politik dalam Media Massa. Granit, Jakarta. 2004.

[13] Howley, K. Understanding Media Community. Thousands Oak. CA: SAGE Publications, Ltd. 2003.

[14] http://disabilityplanet.co.uk/critical-analysis.html/October29,2017, at 14.56. Zhang, Lingling. \& Beth Haller. (2013). Consuming Image: How Mass Media Impact the Identity of People with Disabilities.Cоттиnication QuarterlyVol. 61, No. 3, July-August 2013, pp. 319-334 